\title{
PENYULUHAN BEKAM PADA TERAPIS MASSAGE PEMULA KARANGANYAR DI SMART CLINIC COLOMADU
}

\author{
Wisnu Mahardika $^{1)}$, Widagdo ${ }^{2)}$, Danang Adhi Kusuma ${ }^{3)}$, Rustam yuliyanto ${ }^{4)}$ \\ ${ }^{1223 \$)}$ Pendidikan Kepelatihan Olahraga, Fakultas Keguruan dan Ilmu Pendidikan, Universitas Tunas Pembangunan, \\ Surakarta \\ Corresponding author : Wisnu Mahardia \\ E-mail : wisnu.mahardika@gmail.com
}

\begin{abstract}
ABSTRAK
Kegiatan pengabdian ini dilaksanakan pada tanggal 26 - 27 Desember 2021 pukul 10.0016.00 WIB bertempat di Smart Clinic Colomadu, Karanganyar. Peserta berjumlah 16 peserta. Peserta sangat antusias untuk mengikuti materi penyuluhan. Sebelum penyuluhan diberikan, secara singkat peserta diberikan materi tentang Dasar teknik Bekam dan Sejarah bekam dalam dunia kesehatan. Metode yang digunakan adalah dengan bentuk kegiatan dalam Penyuluhan Bekam pada terapis massage pemula dengan menggunakan pendekatan langsung, demontrasi, diskusi, praktek dan evaluasi terhadap serapan dari terapis massage pemula yang ikut langsung di lokasi yaitu di Smart Clinic Colomadu, dengan teori dan langsung praktek di dilapangan. Penyuluhan ini diberikan supaya peserta mengetahui dan memahami tentang penerapan bekam dalam pasien secara langsung untuk menyembuhkan dan mengembalikan kebugaran pasien. Materi yang saya sampaikan pada kegiatan ini adalah mengenai Penyuluhan Bekam Pada Terapis Massage Pemula Karanganyar di Smart Clinic Colomadu.
\end{abstract}

Kata Kunci : Penyuluhan, Bekam

\section{ABSTRACT}

ABSTRAC

This service activity will be held on December 26-27 2021 at 10.00-16.00 WIB at Smart Clinic Colomadu, Karanganyar. There are 16 participants. Participants were very enthusiastic about participating in the counseling material. Before the counseling was given, participants were briefly given material about the basics of cupping techniques and the history of cupping in the world of health.The method used is in the form of activities in Cupping Counseling for beginner massage therapists using a direct approach, demonstration, discussion, practice and evaluation of the absorption of novice massage therapists who participate directly at the location, namely at the Smart Clinic Colomadu, with theory and direct practice in the field. This counseling is given so that participants know and understand the application of cupping in patients directly to heal and restore patient fitness.The material I convey in this activity is about Cupping Counseling for Beginner Massage Therapists in Karanganyar at Smart Clinic Colomadu.

\section{Keywords: Counseling, Cupping}

\section{PENDAHULUAN}

Dunia kesehatan mengakui perkembangan massage di Indonesia sangat berkembang pesat. Dengan salah satu perkembangan dari massage itu sendiri adalah bekam. Bekam sangat popule karena pelaksanaannya sangat mudah.dengan bekam yang paling di sukai masyarakat adalam bekam basah dan bekam kering. Bekam kering sendiri adalah salah satu teknik dalam bekam yang tanpa ada goresan ataupun sayatan pada bagian tubuh yang di bekam atau sering juga disebut bekam angin. Bekam basah sendiri adalah salah satu teknik bekam dengan memberikan sayatan ataupun 
menggoreskan pada titik bekam untuk dapat menyedot darah dalam permukaan kulit yang telah dibekam. [1]

Manfaat yang diperoleh dalam proses pelaksanaan terapi bekam sendiri adalah mengeluarkan racun, melancarkan peredaran darah, mengatasi demam, mengatasi kelelahan, meredakan nyeri dan keluhan, menyembuhkan banyak penyakit, mengobati banyak masalah kulit, memperbaiki beberapa sistem tubuh dan menghilangkan sihir.

Sasaran kegiatan ini adalah terapis massage pemula yang butuh bekal keahlian dalam melakukan pekerjaan bekam sebagai terapis di dunia masyarakat yang akan diadakan di smart clinic colomadu karanganyar. Tujuan kegiatan ini untuk memberikan pengetahuan dan keterampilan bekam dalam menangani pasien dalam menyembuhkan penyakit. Target pengabdian ini adalah untuk masyarakat umum yang baru belajar massage atau pemula terutama di bidang bekam.

Kunci kesehatan dalam tubuh manusia ada tigal hal yang penting yaitu berkaitan dengan mengkonsumsi makanan, vitamin dan suplemen untuk menjaga kesehatan tubuh, berusaha menghindari makanan ataupun minuman yang membahayakan terhadap kesehatan tubuh dan menjaga kebugaran, dan antibodi yang kuat agar tidak mudah terjangkit penyakit dari luar dan lingkungan sekitar. Pemeliharan tersebut tentunya harus didukung oleh olahraga teratur, menjaga pola makan dan minum yang baik, serta terapi terhadap peningaktan kesegaran jasmani dengan berbagai macam terapi yang berkembang sekarang. [2]

Bekam atau Hijamah adalah suatu metode terapi penyembuhan dan pengobatan dengan cara menghisap kulit dan jaringan di bawah kulit menggunakan cop dari gelas, plastik atau tanduk sehingga darah mengumpul di bawah kulit, kemudian darah yang terkumpul dikeluarkan dari kulit dengan sayatan, tusukan jarum dan hisapan. Terapi bekam dipercaya sebagai media penyembuhan dengan cara mengeluarkan zat toksik yang tidak termetabolisme oleh tubuh melalui permukaan kulit. Terapi bekam sendiri sangat membantu dalam memperlancar peredaran darah, penyumbatan darah dan pengeluran racun dalam sel darah.[1]

Program Tridarma Perguruan Tinggi merupakan program bermanfaat yang mengharuskan dosen selain menjadi tenaga pengajar juga menjadi tenaga pengabdi yang berguna untuk seluruh rakyat Indonesia. Pengabdian ini banyak memberikan solusi bagi terapis-terapis pemula untuk menambah kemampuan dalam menyembuhkan penyakit tetapi juga manambah perekonomian bagi yang menekuni dunia terapis terutama bekam.

Mitra ditawarkan sebuah solusi yang perlu segera dilaksanakan untuk menangani segala penyakit dari terapis bekam ini. Kondisi fisik merupakan komponen yang sangat penting dan dari sini pangabdi mengambil judul Penyuluhan Bekam Pada Terapis Massage Pemula Karanganyar Di Smart Clinic Colomadu.

\section{METODOLOGI}

Pelaksanaan Penyuluhan Bekam Pada Terapis Massage Pemula Karanganyar Di Smart Clinic Colomadu ini untuk menyampaikan materi Bekam dengan metode praktek dan metode demonstrasi, sehingga peserta dapat melihat dan mempraktekkan langsung dalam teknik dasar Bekam secara benar. Pengabdian ini dilaksanakan oleh dua praktikan yaitu : Wisnu Mahardika, S.Pd, M.Or (selaku Dosen massage dan ketua pengabdian), dan Widagdo, Danang dan Rustam (sebagai Anggota). Jadwal Pelaksanaan Lama pelaksanaan pengabdian adalah 2 hari, terinci sebagai berikut :

1. Tempat pelaksanaan : Blulukan, Colomadu, Karanganyar

2. Waktu Pelaksanaan : 26-27 Desember 2021, Pukul 10.00-16.00 WIB

3. Alat yang digunakan : Bekam dan Akupoint

4. Pelaksanaan : Penyuluhan Bekam dan Teknik dasar Bekam

\section{HASIL DAN PEMBAHASAN}

Kegiatan pengabdian ini dilaksanakan pada tanggal 26-27 Desember 2021 pukul 10.0016.00 WIB bertempat di Smart Clinic Colomadu Karanganyar. Peserta berjumlah 16 peserta. Peserta sangat antusias untuk mengikuti materi penyuluhan ini. Sebelum penyuluhan diberikan, secara singkat peserta diberikan materi tentang Dasar teknik Bekam dan Sejarah bekam dalam dunia kesehatan.

Panitia diharapkan mengadakan penyuluhan bekam secara bertahap supaya materi bekam bisa dikenal lebih banyak lagi di kalangan masyarakat secara umum. Dengan Materi yang saya sampaikan pada kegiatan ini adalah mengenai Penyuluhan Bekam Pada Terapis Massage Pemula Karanganyar di Smart Clinic Colomadu. 


\section{SIMPULAN DAN SARAN}

Dari kegiatan pengabdian pada Masyarakat ini dapat disimpulkan bahwa:

1) Penyuluhan Bekam untuk massage pemula sudah terlaksana dengan baik

2) Transfer ilmu dibidang kesehatan terutama massage dengan materi bekam telah berhasil dengan bertambahnya partisipan yang paham tentang pentingnya bekam bagi kesehatan.

Dimulainya sosialisasi yang lebih tentang penyuluhan bekam dan pemanfaatan disiplin ilmunya yang ada

\section{DAFTAR RUJUKAN}

Fatahillah, Ahmad (2006). Keampuhan Bekam (Pencegah \& Penyembuhan Penyakit Warisan Rasulullah.

Jakarta: Qultum Media

Syafiya Al Khaleda (2018). Terapi

Hijâmah (Bekam) Menurut

Pendekatan Sejarah Dan Sunnah .

Tesis. Universitas Islam Negeri

Sumatra Utara : Medan. 